AperTO - Archivio Istituzionale Open Access dell'Università di Torino

\title{
Antiphospholipid antibodies: crossroads between autoimmunity and infections?
}

\section{This is the author's manuscript}

Original Citation:

Availability:

This version is available http://hdl.handle.net/2318/1634194

since 2019-02-13T13:07:56Z

Published version:

DOI:10.1007/s11739-017-1664-2

Terms of use:

Open Access

Anyone can freely access the full text of works made available as "Open Access". Works made available under a Creative Commons license can be used according to the terms and conditions of said license. Use of all other works requires consent of the right holder (author or publisher) if not exempted from copyright protection by the applicable law. 
This is the author's final version of the contribution published as:

Sciascia, Savino; Radin, Massimo; Bazzan, Mario; Roccatello, Dario. Antiphospholipid antibodies: crossroads between autoimmunity and infections? INTERNAL AND EMERGENCY MEDICINE. None pp: 1-2. DOI: $10.1007 / \mathrm{s} 11739-017-1664-2$

The publisher's version is available at:

http://link.springer.com/10.1007/s11739-017-1664-2

When citing, please refer to the published version.

Link to this full text:

http://hdl.handle.net/2318/1634194 
Antiphospholipid antibodies: crossroads between autoimmunity and infections?

Sciascia Savino ${ }^{1,2}$, Radin Massimo ${ }^{1}$, Bazzan Mario $^{3}$, Roccatello Dario ${ }^{1,2}$

1.Center of Research of Immunopathology and Rare Diseases- Coordinating Center of Piemonte and Valle d'Aosta Network for Rare Diseases, Department of Clinical and

Biological Sciences, S. Giovanni Bosco Hospital and University of Turin, Turin, Italy.

2. SCDU Nephrology and Dialysis, S. Giovanni Bosco Hospital, Turin, Italy.

3. UOSD Hematology and Thrombosis Unit, S. Giovanni Bosco Hospital, Turin, Italy.

\section{Corresponding Author:}

Savino Sciascia, MD, PhD;

Center of Research of Immunopathology and Rare Diseases- Coordinating Center of Piemonte and Valle d'Aosta Network for Rare Diseases, and SCDU Nephrology and Dialysis, S. Giovanni Bosco Hospital

Piazza del Donatore di Sangue 3, 10154, Turin, Italy.

Email savino.sciascia@unito.it Tel +390112402056 Fax +390112402052 
We read with interest the letter by Ponzetto and co-workers [1] commenting on our recently published Point of View paper [2]. They propose the hypothesis that testing for Helicobacter pylori (HP) and, when positive, managing that underling infection might improve the current management of some patients with antiphospholipid syndrome (APS). Of note, they highlighted that HP's eradication might result in loss of antiphospholipid antibodies (aPL)[3]. There are several mechanisms through which pathogens can initiate or perpetuate autoimmunity and, while the factors causing production of aPL remain undefined, there is evidence that molecular mimicry is one of the mechanisms by which experimental APS can occur in association with certain pathogens [4]. However, when reviewing the available data on the topic, Abdel-Wahab at al. showed that, although the development of aPL with all traditional manifestations of APS were observed after variety of infections (mainly chronic viral infections including HIV and HCV), the causal relationship between infections and APS is still on debate [5]. Clinical evidences support that infections can trigger the development of catastrophic APS [6]; nevertheless, the possible contribution of various infections in the pathogenesis of APS need further longitudinal and controlled studies to establish the incidence, and to better quantify the risk and the outcomes of aPL-related events after infection.

Finally, an important question still remains: is the aPL negativizationenough to change the therapeutic approach in a patient with APS? Recent data suggest that persistent negative aPL profile is not an indication to interrupt oral anticoagulant therapy as patients are still at high risk of recurrences [7]. 
References:

1. Ponzetto A, Figura N, Caccioppo A (2017) Anti-phospholipid syndrome therapy. Intern Emerg Med. doi: 10.1007/s11739-017-1633-9

2. Sciascia S, Radin M, Bazzan M, Roccatello D (2017) Novel diagnostic and therapeutic frontiers in thrombotic anti-phospholipid syndrome. Intern Emerg Med 12:1-7. doi: 10.1007/s11739-016-1596-2

3. Cicconi V, Carloni E, Franceschi F, et al (2001) Disappearance of antiphospholipid antibodies syndrome after Helicobacter pylori eradication. Am J Med 111:163-4.

4. Cruz-Tapias P, Blank M, Anaya J-M, Shoenfeld Y (2012) Infections and vaccines in the etiology of antiphospholipid syndrome. Curr Opin Rheumatol 24:389-393. doi: 10.1097/BOR.0b013e32835448b8

5. Abdel-Wahab N, Lopez-Olivo MA, Pinto-Patarroyo GP, Suarez-Almazor ME (2016) Systematic review of case reports of antiphospholipid syndrome following infection. Lupus. doi: 10.1177/0961203316640912

6. Sciascia S, Lopez-Pedrera C, Roccatello D, Cuadrado MJ (2012) Catastrophic antiphospholipid syndrome (CAPS). Best Pract Res Clin Rheumatol. doi: 10.1016/j.berh.2012.07.005

7. Medina G, Briones-García E, Cruz-Domínguez MP, et al (2017) Antiphospholipid antibodies disappearance in primary antiphospholipid syndrome: Thrombosis recurrence. Autoimmun Rev. doi: 10.1016/j.autrev.2017.02.004 